\title{
Estonia's competition policy: a critical evaluation towards EU accession
}

Citation for published version (APA):

Schinkel, M. P., \& Thielert, J. (2002). Estonia's competition policy: a critical evaluation towards EU accession. METEOR, Maastricht University School of Business and Economics. METEOR Research Memorandum No. 020 https://doi.org/10.26481/umamet.2002020

Document status and date:

Published: 01/01/2002

DOI:

10.26481/umamet.2002020

Document Version:

Publisher's PDF, also known as Version of record

\section{Please check the document version of this publication:}

- A submitted manuscript is the version of the article upon submission and before peer-review. There can be important differences between the submitted version and the official published version of record.

People interested in the research are advised to contact the author for the final version of the publication, or visit the DOI to the publisher's website.

- The final author version and the galley proof are versions of the publication after peer review.

- The final published version features the final layout of the paper including the volume, issue and page numbers.

Link to publication

\footnotetext{
General rights rights.

- You may freely distribute the URL identifying the publication in the public portal. please follow below link for the End User Agreement:

www.umlib.nl/taverne-license

Take down policy

If you believe that this document breaches copyright please contact us at:

repository@maastrichtuniversity.nl

providing details and we will investigate your claim.
}

Copyright and moral rights for the publications made accessible in the public portal are retained by the authors and/or other copyright owners and it is a condition of accessing publications that users recognise and abide by the legal requirements associated with these

- Users may download and print one copy of any publication from the public portal for the purpose of private study or research.

- You may not further distribute the material or use it for any profit-making activity or commercial gain

If the publication is distributed under the terms of Article $25 \mathrm{fa}$ of the Dutch Copyright Act, indicated by the "Taverne" license above, 


\title{
Estonia's Competition Policy: A Critical Evaluation towards EU Accession
}

\author{
Maarten Pieter Schinkel* \\ Julia Thielert $^{* *}$
}

\section{Introduction}

Forty-five years after the Treaty of Rome (1957), the European Union stands before yet another pivotal point in its development, extension towards the East. Negotiations are under way with twelve formerly communist Central and Eastern European countries that have applied for admission. ${ }^{1}$ In its history, the Union has already seen the successful integration of new members. Yet, the current round of enlargement is unprecedented both in terms of scope and diversity: should all applicant countries join the European Union, its area will increase by 34 per cent and its population by 105 million people. Also, the new countries will bring a wealth of different histories and cultures to the EU.

Accession negotiations with those applicant countries that are ready for membership are to be concluded by the end of 2002, so that they will be able to take part as members in the European Parliament's elections of 2004. Besides political and economic stability, the applicant's adoption of the Union's common legislation, i.e. the acquis communautaire, is an essential precondition for admittance. $^{2}$ More specifically, countries' competition policies play a central role in the evaluation for accession. The European Commissioner for Competition Policy, Mario Monti, has made it clear that a true competition discipline, consisting of a sufficient legal framework for antitrust, efficient administrative capacity and a concrete antitrust enforcement record, is of utmost

\footnotetext{
* Assistant Professor of Economics, Department of Economics, Universiteit Maastricht, The Netherlands.

${ }^{* *}$ Candidate for Master of Economics, Department of Economics, Universiteit Maastricht, The Netherlands.

${ }^{1}$ Bulgaria, Cyprus, the Czech Republic, Estonia, Lithuania, Latvia, Malta, Hungary, Poland, Romania, Slovakia, and

Slovenia. Turkey has applied for membership as well, but there are currently no accession negotiations between it and the Union (see the internet page of the DG Enlargement of the European Union).

${ }^{2}$ Competition policy usually comprises antitrust and state-aid policy. However, an analysis of state aid regulations would be beyond the scope of this paper. Thus, competition policy is used here synonymously with antitrust policy.
} 
importance for those countries that want to join the European Union in the near future. ${ }^{3}$ In a speech delivered at the $7^{\text {th }}$ Annual Competition Conference between Candidate countries and the European Union in June 2001, Monti warned that without a strict competition discipline preventing any market-distorting behaviour of undertakings: “...the market economy is unlikely to deliver the advantages it promises..." and the formerly centrally-planned economies will be unable to survive the competitive pressures and market forces of the internal market. ${ }^{4}$

After the collapse of communism in the early 1990s, the Baltic countries were among the first Central and Eastern European countries to introduce political and economic reforms. Like Lithuania and Latvia, the country of Estonia declared its independence from the Soviet Union in 1991 and has since then pursued a liberal free-trade policy, resulting in the rapid transition from its centrally planned system to a market economy. However, Estonia was quicker than its neighbours to apply for EU membership. It did so on 24 November 1995 - whereas Latvia and Lithuania applied only in 1998 - and negotiations about the country's accession were started in March 1998.

Even before its application for EU accession, Estonia introduced antitrust laws. The first Estonian Competition Act was issued in 1993 and amended in 1998. Only recently, however, on 1 October 2001, the Competition Act 2001 entered into force, the first Act that gives Estonian competition authorities the right to prohibit anti-competitive mergers. ${ }^{5}$ Soon after, on 28 November 2001, negotiations on competition policy between Estonia and the European Union were provisionally closed, implying that Estonia's laws are now adequately in line with EU legislation. ${ }^{6}$ Therefore, it now is the appropriate time to ask to what extent Estonia has managed the task of aligning its competition law with EU legislation. Did it simply copy the European laws, or can one identify national characteristics and features that differentiate the country's policy in the field of antitrust? And more importantly, how effective is the Estonian enforcement of existing law?

\section{Competition policy in Estonia}

Estonia's first Competition Act of June 1993, which entered into force on 1 October 1993, enacted the principles of competition policy with respect to the prohibition of concerted practices and the

\footnotetext{
${ }^{3}$ Monti (2001), p.4.

${ }^{4}$ Op.cit., pp.2-3.

${ }^{5}$ See Kalaus (2002) for a detailed layout of Estonian merger control regulation.
} 
abuse of dominance. It did not have provisions for merger control. The Act created the Estonian Competition Board (ECB) as the authority responsible for enforcing the competition rules. In June and November 1995 respectively, Estonia signed an Association Agreement with the EU, and applied for accession. This, together with the experiences its authorities gained with competition policy issues while the country improved on its transition path towards a market economy, made amendments to the Competition Act and further alignment with EU policy necessary. A new version of the Competition Act was passed in 1998. Although it introduced a pre-notification requirement for mergers if the aggregate annual turnover of the parties exceeded 100 million kroons (ca. 6.4 million $€$ ) or if the merging parties separately or jointly had control over more than 40 per cent of the market, it offered no provisions for the prohibition of competition-distorting mergers. This defect was repaired in the latest version of the Estonian Competition Act, entered into force on 1 October 2001, which explicitly grants the Competition Board the power to prohibit anti-competitive mergers. ${ }^{7}$

\subsection{Legislation}

Before reviewing its specifics, it is important to note that the provisions of the Estonian antitrust legislation do not only apply to undertakings, but according to $\S 2.2$ of the Competition Act 2001 the earlier Acts included the same phrase - also to "persons who perform functions in public law and to the state and local governments if they participate in a goods market." This is a characteristic of law that Estonia shares with several other transition countries. ${ }^{8}$ Although the ECB is not entitled to levy fines on government authorities, it can recommend that those should terminate their competition-distorting behaviour.

\subsubsection{Prohibition of concerted practices}

In the Competition Act 2001, chapter 2 deals with the prohibition of horizontal and vertical agreements, concerted practices and decisions by associations of undertakings. Specifically, $\S 4.1$ prohibits:

\footnotetext{
${ }^{6}$ Negotiations were concluded at the Accession Conference's meeting at Deputies' level on 28 November 2001 and this result was subsequently confirmed by the meeting of the Accession Conference at Ministerial level on 12 December 2001.

${ }^{7}$ Estonian Competition Board (2000), p. 19. See also Kalaus (2002).

${ }^{8}$ OECD (1999), p. 39.
} 
“...agreements between undertakings, concerted practices and decisions by associations of undertakings... which have as their object or effect the restriction of competition, including those which:

1) directly or indirectly fix prices or any other trading conditions, including prices of goods, tariffs, fees, mark-ups, discounts, rebates, basic fees, premiums, additional fees, interest rates, rent or lease payments applicable to third parties;

2) limit production, service, goods markets, technical development or investment;

3) share goods markets or sources of supply, including restriction of access by a third party to a goods market or any attempt to exclude the person from the market;

4) exchange information which restricts competition;

5) agree on the application of dissimilar conditions to equivalent agreements, thereby placing other trading parties at a competitive disadvantage;

6) make entry into an agreement subject to acceptance by the other parties of supplementary obligations which have no connection with the subject of such agreement.",9

In $\S 8$ of the Competition Act, such agreements, practices or decisions are declared to be void unless they are of "minor importance." According to $\S 5.2$ :

“...agreements, practices and decisions are of minor importance if the combined market share of the total turnover of the undertakings...does not exceed:

1) 10 per cent in the case of a vertical agreement, practice or decision;

2) 5 per cent in the case of a horizontal agreement, practice or decision;

3) 5 per cent in the case of an agreement, practice or decision which includes currently the characteristics of both vertical and horizontal agreements practices or decisions. "10

While agreements fulfilling these conditions are automatically liberated from $\S 4.1$, undertakings may also apply for an exemption of their agreements or practices under $\S 6$. Such an exemption may be granted:

"... if the agreement, practice or decision:

1) contributes to improving the production or distribution of goods or to promoting technical or economic progress or to protecting the environment, while allowing consumers a fair share of the resulting benefit;

\footnotetext{
${ }^{9}$ The original Act is available in English. $\S 4.1$ does not apply to the agricultural sector "unless competition is substantially restricted by such agreements, practices or decisions" (§ 4.2).

${ }^{10}$ These conditions must be fulfilled during the whole period of effect of the agreement, practice or decision (§ 5.4).
} 
2) does not impose on undertakings which enter into the agreement, engage in concerted practices or adopt the decision any restrictions which are not indispensable to the attainment of the objectives specified in clause 1) of this subsection;

3) does not afford the undertakings which enter into the agreement, engage in concerted practices or adopt the decision the possibility of eliminating competition in respect of a substantial part of the goods market."

In order to obtain an exemption under $\S 6$, the partners to the agreement, practice or decision must notify their conduct to the ECB, which then decides whether the conditions of $\S 6$ are fulfilled. ${ }^{11}$ Apart from the individual application for exemptions, the Competition Act also provides for block exemptions $(\S 7)$, which can be granted by a government regulation and free the undertakings concerned from the notification requirement. At the moment, there are four block exemptions in force in Estonia: for franchise agreements, exclusive purchase agreements, exclusive distribution agreements and motor vehicle and servicing agreements. ${ }^{12}$ However, the Competition Act includes a "safeguard clause" with respect to the application of block exemptions:

“A block exemption established on the basis of subsection (1) of this section does not apply:

1) to an undertaking in a dominant position;

2) if competition is virtually non-existent in the goods market affected by the agreement, practices or decision." 13

\subsubsection{Prohibition of the abuse of a dominant position}

As in EU legislation, the Estonian Competition Act does not prohibit the existence of a dominant position per se, but only the abuse of it. The Act deals with this issue in chapter 4 and states in $\S$ 16 that:

"The following are prohibited: any direct or indirect abuse by an undertaking in a dominant position of his or her position in the goods market, including:

1) directly or indirectly imposing unfair purchase or selling prices or other trading conditions;

2) limiting production, service, goods markets, technical development or investment;

\footnotetext{
${ }^{11}$ When exempting an agreement or concerted practice, the Board may impose conditions or obligations on the undertakings involved.

${ }^{12}$ www.konkurentsiamet.ee/gb/legislation.html, accessed 19.01.2001.

13 Competition Act 2001, § 7.3.
} 
3) offering or applying dissimilar conditions to equivalent agreements with other trading partners, thereby placing some of them at a competitive disadvantage;

4) making entry into an agreement subject to acceptance by the other parties of supplementary obligations which have no connection with the subject of such agreement;

5) forcing an undertaking to concentrate, enter into an agreement which restricts competition, engage in concerted practices or adopt a decision together with the undertaking or another undertaking;

6) unjustified refusal to sell or buy goods;

7) failure by an undertaking with special or exclusive rights or in control of essential facilities to perform the obligations specified in clause 18 (1) 1) of this Act."

In $\S 13$, the Competition Act explicitly defines what is to be considered as "dominance":

"For the purposes of this Act, an undertaking in a dominant position is an undertaking which accounts for at least 40 per cent of the turnover in the goods market or whose position enables the undertaking to operate in the market to an appreciable extent independently of competitors, suppliers and buyers. ",14

In $\S 13.2$, undertakings with special or exclusive rights ${ }^{15}$ or in control of essential facilities ${ }^{16}$ are also defined as being in a dominant position. In $\S \S 17$ and 18 , the Competition Act lists several restrictions and obligations that apply to these undertakings. Firstly, government authorities may prescribe the prices to be charged, or impose other conditions or obligations on the undertakings concerned, so that consumers "are not placed in a substantially worse situation than they would if competition were present in the corresponding area of activity." ${ }^{17}$ Secondly, the undertakings must draw a clear distinction in their accounts between primary and secondary activities in order to ensure accounting transparency. ${ }^{18}$ Thirdly, they must permit other undertakings access to their network, infrastructure or essential facility under reasonable and non-discriminatory conditions unless there are safety, security or efficiency reasons for not granting access, problems of technical

\footnotetext{
${ }^{14}$ Competition Act 2001, § 13.1 .

${ }^{15}$ According to $\S 14$, these are undertakings that have special or exclusive rights granted by the state or a local government, which give them a competitive advantage over other undertakings in the market or enable them to be the only undertaking in the market.

${ }^{16}$ Such undertakings are, according to $\S 15$, undertakings that own, possess or operate a network, infrastructure or any other essential facility which other persons cannot duplicate or for whom it is economically inexpedient to duplicate (i.e. a natural monopoly), but without access to which or the existence of which it is impossible to operate in the goods market.

${ }^{17}$ Competition Act 2001, §§ 17.1 and 17.2.

${ }^{18}$ Competition Act 2001, § 18.2.
} 
non-conformity or unless access of competitors would put at risk the data protection provided for by law. ${ }^{19}$

\subsubsection{Merger control}

The Competition Act 2001 introduced sections on merger control. According to $\S 21$, the parties to a merger must notify their concentration plans to the ECB if:

“...during the previous financial year, the aggregate worldwide turnover of the parties to the concentration exceeded 500 million kroons [ca. 40 million $€$ ] and the aggregate worldwide turnover of each of at least two parties to the concentration exceeded 100 million kroons [ca. 6.4 million $€$ ] and if the business activities of at least one of the merging undertakings... are carried out in Estonia."

$\S 22.2$ gives the ECB the right to prohibit a concentration "if it may create or strengthen a dominant position as a result of which competition would be significantly restricted in the goods market." According to $\S 22.1$, appraisal of a merger shall be based on the need to maintain and develop competition, taking into account the structure of the respective markets, actual and potential competition, legal or other barriers to entry, supply and demand trends for the relevant goods and the interests of buyers, sellers and ultimate consumers.

Once a planned concentration has been notified by the partners involved, the ECB is held to decide within thirty calendar days whether to permit the merger or whether to initiate supplementary investigations into its possibly anti-competitive effects. If supplementary investigations are conducted, these may last no longer than four months. After this period, a final decision - appraisal or prohibition of the merger - must be communicated to the undertakings concerned. $^{20}$ The ECB may make its appraisal of a concentration conditional on certain obligations in order to avoid a restriction of competition. ${ }^{21}$

\subsection{Enforcement}

The Estonian Competition Board, responsible for the enforcement of Estonian competition legislation by the 1993 Competition Act, is established within the Estonian Ministry of Finance. However, it is technically not a part of this Ministry and can therefore be considered as

\footnotetext{
${ }^{19}$ See Competition Act $2001, \S 18.2$ for a detailed list of reasons that might justify the refusal to grant access.

${ }^{20}$ Competition Act 2001, $\$ 27$.

${ }^{21}$ Competition Act 2001, § 27.3.
} 
independent in its decisions. ${ }^{22}$ The Board is headed by a Director General, who is appointed to and removed from office by the Minister of Finance upon recommendation of the Ministry's Secretary General. ${ }^{23}$

Until March 2000, the organisation of the departments of the ECB closely followed the structure of the Competition Act: the Department of Market Relations was dealing with matters involving abuse of dominance and mergers; the Department of Agreements was responsible for restrictive agreements, concerted practices and the supervision of individual and block exemptions; the Department of External and Public Relations dealt with competition authorities of other countries, matters relating to European integration, training and information issues; and the Legal Department provided legal services to other departments and was involved in the drafting of competition legislation. While the latter two remained unchanged, the Departments of Market Relations and Agreements were reorganised in 2000 into three separate divisions that are specialised in comparatively limited economic sectors: the Energetic and Communications Department, the Foodstuffs and Services Department, and the Product Markets Department. They each deal both with concerted-practices and dominant-position cases. Finally, in expectation of the new Competition Act in 2001, a new Merger Department was established in 2000 that is responsible for controlling mergers in all economic sectors. ${ }^{24}$

According to $\S 65.2$ of the Competition Act 2001, the ECB can initiate investigations and proceedings concerning a case on its own initiative. Besides this public enforcement, there is the possibility of private enforcement. $\S 64$ of the 2001 Competition Act states that any private legal person has the right to submit an appeal to the ECB if he finds that competition has been restricted and his rights have been violated. The ECB is then to decide within 30 calendar days whether to initiate proceedings or not. ${ }^{25}$

During proceedings, the ECB has far-reaching investigative powers, which are laid out in $\S \S$ 57-60 of the Competition Act. Firstly, the ECB may request all natural and legal persons and all state agencies and local governments to submit any information necessary for its investigations an extensive list of which is given in $\S 57.1$. Also, officials of the Board have the right to inspect, authorised by a directive of the Board's Director General, the seat or place of business of

\footnotetext{
${ }^{22}$ OECD (1999), p. 46.

${ }^{23}$ OECD (1999), pp.27 and 46.

${ }^{24}$ OECD (1999), pp. 27-28, Estonian Competition Board (2000), p. 2.

${ }^{25}$ Competition Act 2001, § 65.1.
} 
undertakings, to examine and copy documents and electronic files and to request explanations from the undertaking's representatives. ${ }^{26}$

If the ECB finds that the Competition Act has been violated, it may levy fines on the undertakings involved. This possibility was first introduced by the 1998 Competition Act, which foresaw fines of up to 5 per cent of the turnover of the offending party in the previous year. ${ }^{27}$ In 2001, the upper limit for fines was increased to 10 per cent of the offender's turnover during the previous financial year. Such fines can be levied for engaging in concerted practices, for the abuse of a dominant position, failure to notify a merger, violating the prohibition of a merger or violating the conditions attached to its appraisal. If the ECB finds that undertakings with special or exclusive rights or in control of essential facilities have failed to draw a clear distinction between their primary and secondary activities in their accounts, i.e. are in violation of $\S 18.2$, it may levy fines of up to 1 per cent of the offender's turnover during the previous financial. ${ }^{28}$ According to $\S$ 73 of the Competition Act, undertakings have the right to appeal against the decisions of the ECB in court.

\section{Comparison of Estonian competition policy to EU policy}

\subsection{Legislation}

A first thing that meets the eye when comparing the EU's and Estonia's legislation on antitrust is that Estonian legislation is much more "compact" than EU legislation. While the European Union's rules on concerted practices, dominant firms and merger control are distributed between the EC Treaty (Articles 81 and 82) and two Council regulations (17/62 and 4064/89), the Estonian Competition Act combines the laws with respect to all three pillars of antitrust in one document. This obviously enhances the transparency of law.

Since the explicit aim of all recent amendments of the Estonian Competition Act was to bring legislation further in line with EU legislation, it is no surprise that the Estonian antitrust laws are almost identical to the laws of the European Union, often even in their wording. ${ }^{29} \S 4.1$ of the Estonian Competition Act 2001, for example, is more or less a copy of Article 81.1 of the EC Treaty, prohibiting "all agreements that have as their object or effect the prevention or restriction of competition." Likewise, $\S 16$ on the abuse of dominance is identical to Article 82 of the EC

\footnotetext{
${ }^{26}$ Competition Act 2001, § 60 .

${ }^{27}$ OECD (1999), p.49.

${ }^{28}$ Competition Act 2001, § 75. This is in accordance with the 1998 Act.
} 
Treaty. Still, compared to EU legislation, the Estonian Competition Act is often more explicit and comprehensive. With respect to prohibited concerted practices and agreements, the Estonian Competition Act lists examples that are not explicitly dealt with in Article 81: the attempt to restrict or the actual restriction of a person's access to a goods market and the exchange of information which restricts competition (§ 4.1.3 and $\S 4.1 .4)$.

However, the European nor the Estonian listing is exhaustive, or meant to be. Rather, they are examples of anti-competitive practices. Thus, although the EU does not mention these practices explicitly, they are prohibited under Article 82 if they have as their object or effect the prevention or restriction of competition. Although, therefore, the extensive amount of examples in the Competition Act (also in $\S 16$ compared to Article 82) could be considered redundant, making the legislative text longer than strictly necessary, it serves a purpose. Estonia does not have a long tradition in antitrust policy. Hence, undertakings do not have much experience with the competition authorities yet and there is little information available on previous decisions of the ECB. The absence of case law as a source of information and a guide to the interpretation of law is obviated by an explicit wording of the antitrust laws, thus preventing, possibly unintentional, illegal behaviour, reducing the workload of ECB, and increasing overall efficiency.

A final feature of Estonian competition law, not found in its European mater, is its application to government authorities. In a transition economy such as the Estonian, it is meant to increase trust in government authorities. It also helps to educate them. Although the ECB does not have the right to issue an offence against governments, namely, it has been active in matters involving government activities in 33 cases since 1993. Often, it achieved by means of mere exposure that the offending agencies terminated their anti-competitive conduct. By eliminating unnecessary and anti-competitive government regulations, the application of antitrust laws to government agencies substantially benefits consumers and can therefore - as the OECD puts it be considered as "an efficient use of a competition agency's limited resources."

In summary, the structures of EU and Estonia antitrust legislation compare as given in the table below.

\footnotetext{
${ }^{29}$ Compare Estonian Competition Board (2000), p. 3.

${ }^{30}$ OECD (1999), p. 40.
} 


\begin{tabular}{|l|l|l|}
\hline & Estonia & EU \\
\hline Prohibition of concerted & $\begin{array}{l}\text { Competition Act 2001, } \\
\text { Chapters } 2 \text { and } 3(\S \S 4-12)\end{array}$ & EC Treaty, Article 81 \\
\hline $\begin{array}{l}\text { Prohibition of the abuse of a } \\
\text { dominant position }\end{array}$ & $\begin{array}{l}\text { Competition Act 2001, } \\
\text { Chapter } 4(\S \S 13-18)\end{array}$ & EC Treaty, Article 82 \\
\hline Merger control & $\begin{array}{l}\text { Competition Act } 2001, \\
\text { Chapter 5 (\$§19-28) }\end{array}$ & Regulation 4064/89 \\
\hline
\end{tabular}

Table 1: Overview of antitrust legislation in Estonia and the EU

\subsubsection{Prohibition of concerted practices}

In general, Estonian legislation on competition-distorting agreements and concerted practices is very similar to EU legislation. Both $\S 4.1$ of the Competition Act and Article 81.1 of the EC Treaty prohibit agreements that have as their effect the prevention or distortion of competition. Moreover, both legislations grant undertakings the right to obtain, on application, an exemption from Article 81.1 and $\S 14.1$ respectively if their agreements or practices contribute to technical or economic development, allow consumers a fair share of the resulting benefits and at the same time are not more restrictive than necessary and do not eliminate competition in the respective market. Finally, Estonia has introduced the EU's system of block exemptions that liberate certain agreements from the notification requirement and thereby facilitate procedures for the undertakings concerned and the competition authorities themselves. But beside these similarities, the Estonian Competition Act 2001 also exhibits some special features with respect to agreements and concerted practice.

In $\S 6$, Estonian law states that - contrary to the rules in the EU - not only agreements or practices that improve economic progress, but also those that promote the protection of the environment can be exempted from $\S 4$.1. Like many transition countries, Estonian suffers from a heritage of high levels of pollution. An exemption clause for concerted practices that benefit the environment should therefore benefit the country as a whole. Although this should have a higher priority in transition countries than in developed economies, a lower pollution level and the protection of the environment are always beneficial for a country and thus also important to the countries of the European Union. It might be worthwhile for the EU to consider including such an exemption clause in Article 81 as well. 
Another difference of the Competition Act to EU law is that it explicitly exempts agreements and practices of "minor importance." Those are agreements and practices between undertakings whose combined market share is below the thresholds laid out in $\S 5.2$, which are automatically exempted from $\S 4.1$ without prior notification. Obviously, this means that some welfare losses due to concerted practices can prevail. However, given the limited resources of the ECB, the "minor importance clause" certainly reduces the bureaucratic burden and allows the Board to concentrate on severe violations of the Act that have stronger negative welfare consequences than agreements between small undertakings. Thus, by freeing resources for the prevention of strongly anti-competitive practices and agreements, the minor importance clause should benefit the Estonian economy overall.

Finally, Estonian competition law includes a "safeguard clause" with respect to block exemptions. $\S 7.3$ states that block exemptions do not apply to firms with a dominant position or if there is virtually no competition in the market concerned. Thus, block exemptions automatically expire if the market structure changes, without the need to withdraw them or initiate detailed investigations. Like the minor importance clause, this provision reduces the bureaucratic burden on the competition authorities.

\subsubsection{Prohibition of the abuse of a dominant position}

The rule in the Estonian Competition Act with respect to dominant firms strongly resemble those of the EC Treaty as well. Both Article 82 of the EC Treaty and $\S 16$ of the Competition Act prohibit the direct or indirect abuse of an undertaking's dominant position and list possible examples of such abuse, including imposing unfair purchase or selling prices, limiting production or technical development, applying dissimilar conditions to equivalent transactions and making the entry into an agreement subject to acceptance by the other parties of supplementary obligations which have no connection with the subject of the agreement. As said, the list of the Estonian law is longer and more comprehensive than the one in Article 82 (forcing an undertaking to concentrate, enter into a competition-restricting agreement or engage in concerted practices and the unjustified refusal to sell or buy goods), but these additional practices are also covered by EU legislation in as far as they represent an abuse of dominance (compare section 3.1.1).

A striking difference between Estonian and EU law on undertakings in a dominant position is that while the EC Treaty does not define "dominance", $\S 13$ of the Competition Act explicitly lays out what is considered as an undertaking in a dominant position under Estonian legislation: 
"an undertaking which accounts for at least 40 per cent of the turnover in the goods market or whose position enables it to operate in the market to an appreciable extent independently of competitors, suppliers and buyers." ${ }^{31}$ As far as the second part of this paragraph is concerned, this is in line with EU policy, since the Commission has used the same definition of dominance in some of its decisions. ${ }^{32}$ However, the strict definition of dominance as a market share of at least 40 per cent is potentially troublesome. According to the theory of contestable markets, "even very high market shares do not confer dominance if entry into the relevant market is not difficult." 33 Thus, the ECB should not automatically conclude that an undertaking with a market share of 40 per cent or more is in a dominant position, but instead also analyse the degree of potential competition from outside the market. ${ }^{34}$ Although the explicit definition of dominance in Estonia could be seen as a measure to increase the Competition Act's transparency, making it easier for undertakings to anticipate the argumentation of the ECB, the definition in terms of rigid market shares can easily lead to erroneous results and should therefore be rethought in future versions of the Competition Act.

Apart from a market share of 40 per cent and the independence from competitors, suppliers and buyers, the Estonian Competition Act lists two other conditions for a dominant position: undertakings with special or exclusive rights and in control of an essential facility are automatically considered as having a dominant position. ${ }^{35} \S 17$ and 18 then list restrictions and obligations applicable to such undertakings. Among other things, they are obliged to permit other undertakings access to their essential facility on non-discriminatory terms. However, the question is whether the explicit mentioning of such undertakings is really necessary. If special or exclusive rights or control over an essential facility give an undertaking a dominant position in a market and the undertaking abuses this position by refusing competitors access to its facility, such cases can easily be dealt with under $\S 16$, making further legislation redundant. In the EU, essential facilities cases are dealt with under Article $82 .{ }^{36}$ Probably, the explicit mentioning of undertakings with special or exclusive rights and in control of essential facilities in Estonian competition law can

\footnotetext{
${ }^{31}$ Competition Act 2001, § 13.1.

${ }^{32}$ E.g. in the Europemballage and Continental Can case, quoted in Fishwick (1989), p. 455.

${ }^{33}$ OECD (1999), p. 31.

${ }^{34}$ According to Fishwick, this is what the European Commission does when assessing whether an undertaking is in a dominant position (see Fishwick (1989), p.455).

${ }^{35}$ An essential facility is an upstream facility or infrastructure whose duplication would be inefficient and without access to which competitors cannot provide downstream services to their customers (see Ridyard (1990), p. 2-3).
} 
again be seen as an attempt to increase transparency and to clearly inform the concerned undertakings about their obligations. According to the OECD, the regulation of network infrastructure industries that depend on essential facilities may often not yet be fully effective in transition economies such as Estonia. ${ }^{37}$ Therefore, the very explicit and comprehensive approach taken by the Estonian Competition Act might be justified. Strictly speaking however, such provisions are redundant.

\subsubsection{Merger control}

The Estonian rules with respect to merger control mimic those of the EU too. Under both legislations, firms planning a merger above certain thresholds must notify their plans in advance to the competition authorities. These may then decide to appraise of or to prohibit the merger, depending on whether it is likely to create or strengthen a dominant position that may result in the prevention or restriction of competition. Not only is most of the wording of the respective paragraphs in the Competition Act, but even the time limits that the ECB must obey are the same as the ones for the European Commission - that is, one month for an initial investigation, and up to four months for a full-scale investigation.

Nonetheless, there is a slight difference between the two laws. In the EU, the pre-notification requirements relate to mergers that have a "community dimension": if the combined world wide turnover of the merging parties exceeds 5 Billion $€ \underline{\text { and }}$ if at least two of the parties have a European turnover of more than 250 million $€$, unless the parties to the merger generate more than two thirds of their respective European turnover within a single EC country. ${ }^{38}$ The Estonian Competition Act requires a merger to be notified if the combined world wide turnover of the merging parties exceeds 500 million kroons (ca. 40 million $€$ ), the aggregate world wide turnover of each of at least two merging parties exceeds 100 million kroons (ca. 6.4 million $€$ ) and if the business activities of at least one of the merging undertakings are carried out in Estonia. However, this last condition is problematic because it does not specify when an undertaking's activities are considered to be carried out in Estonia. Contrary to EU law, the Competition Act does not give a threshold of "Estonian turnover" with which the "Estonia dimension" could be tested. The sole

\footnotetext{
${ }^{36}$ One example was the case between B\&I Line (a ferry operator) and Stena Sealink (a port owner and ferry operator) in 1992, in which Stena Sealink was obliged to supply port services to B\&I Line because its port was considered as an essential facility (see Ridyard, p. 7-8).

${ }^{37}$ OECD (1999), p. 31

${ }^{38}$ Council Regulation 4064/89.
} 
relation to worldwide turnover carries the danger that the ECB will have to deal with mergers that fall under the Competition Act but do not have any anti-competitive effects in Estonia. This would unnecessarily tie up the Board's limited resources. In order to avoid this risk, Estonia should follow the recommendations of the OECD and "consider especially modifying the turnover threshold to include only turnover within Estonia.",39

\subsection{Enforcement}

Both in the European Union and in Estonia, a de facto independent government authority is responsible for the enforcement of competition legislation. Although the ECB is established within the Ministry of Finance, it is considered to be independent in its decisions, which is also true of the Directorate General of the European Commission. ${ }^{40}$

Until March 2000, the structure of the ECB differed substantially from that of the Directorate General Competition of the EU, but today it displays the same organisational characteristics: several departments concentrate on specific industry sectors and are responsible for both concerted practices and the abuse of dominance within these sectors. Moreover, both institutions have special merger departments focusing on merger cases only. Since "sectoral" work arrangements allow the competition officials to follow more closely the developments in "their" sectors and to start with investigations sooner without the need to collect background information, the structural change of the ECB should have positive effects and enable the Board to work more efficiently. ${ }^{41}$

Beside public enforcement of the competition rules, both EU and Estonian legislation provide for the possibility of private enforcement, i.e. private legal persons have the right to file complaints with the authorities if they think that an undertaking violates the competition rules. Also, Estonian law corresponds to EU law in allowing the judicial review of the competition authorities' decisions.

The investigative powers of the ECB are very similar to those of the European Commission. In the course of investigations, both institutions have the right to request any information necessary for their work from the undertakings concerned. Moreover, they are entitled to inspect an undertaking's seat and place of business, to examine and copy any documents and electronic

\footnotetext{
${ }^{39}$ OECD (1999), p. 39.

${ }^{40}$ Op.cit., p. 46.

${ }^{41}$ Compare Estonian Competition Board (2000), p. 2.
} 
files and to demand explanations from the undertaking's representatives. ${ }^{42}$ Under both legislations, these powers relate to cases of concerted practices, dominance and merger control.

Finally, the Competition Board's power to levy fines is an exact copy of EU legislation. As already explained before, the possibility of fines was introduced in Estonia with the 1998 Competition Act and at first allowed fines of up to 5 per cent of the concerned undertaking's turnover during the previous financial year. In the 2001 Act, the upper limit was increased to 10 per cent of the offending undertaking's turnover, which is exactly the limit that Regulations 17/62 and 4064/89 prescribe for the European Commission.

By increasing undertakings' costs of getting caught by the competition authorities, higher fines can act as a deterrent to anti-competitive behaviour and thereby increase overall efficiency in an economy. However, they will only do so if the competition authorities make full use of their powers. The DG Competition of the European Commission traditionally takes a strict view with respect to cartels and abuse of dominance and levied total fines of 199.5 million $€$ in 2000 . $^{43}$ Contrarily, the ECB has been rather reluctant in this respect. The cases of the Taxi services market in Pärnu, Hawaii Express and The Port of Veree, summarised below, illustrate that in its investigations, the Board often relies on co-operation and the undertakings' voluntary termination of anti-competitive behaviour, instead of fines.

\section{The case of Taxi services market in Pärnu ${ }^{44}$}

In the city of Pärnu, five taxi companies accounted for approximately 70 per cent of the total market. In May 1999, three of them introduced the joint use of customer cards: they offered a similar reduced price - 5 kroons per kilometre - to the owners of customer cards of the three different undertakings. ${ }^{45}$ The agreement between the three undertakings became public through a newspaper article, in which a high representative of one of the firms commented on the undertakings' co-operation by saying: "We have come to a decision together with Bristol Takso and Ranna Takso [the other two companies involved] that the citizens of Pärnu deserve to have discounts. "46

\footnotetext{
${ }^{42}$ Competition Act 2001, § 60, Regulation 17/62, Article 14 and Regulation 4064/89, Article 13.

${ }^{43}$ European Commission (2001a).

${ }^{44}$ Based on Estonian Competition Board (2000), pp. 10-11.

${ }^{45}$ According to the undertakings concerned, this was designed as a countermeasure against another taxi company that had established a special price of 5 kroons per kilometre for owners of its customer card earlier that year.

${ }^{46}$ Estonian Competition Board (2000), p. 10.
} 
On 17 May 1999, the Competition Board initiated proceedings in this case, alleging a violation of $\$ 4$ of the Competition Act. The Board argued that while the joint use of customer cards might benefit consumers in the short run through reduced tariffs, it would not do so in a longer perspective. By agreeing on price reductions, the three undertakings effectively weakened competition in prices compared to a situation in which each of them would decide on price reductions independently. Also, the Board held that the joint dominance of the three firms together they accounted for more than 40 per cent of the taxi market in Pärnu - would enable them in the long run to increase both their basic and reduced tariffs to economically unjustified levels. Undertakings with lower market shares would follow in order to increase their profits, resulting in unjustifiably high prices on the market and thus harming consumers. On 29 December 1999, the Board officially established an offence of the Competition Act and requested the three undertakings involved to terminate their practice. Moreover, it levied a fine of 10,000 kroons on each of them.

\section{The case of Hawaii Express ${ }^{47}$}

Hawaii Express (HE), a leading distributor of sports and leisure goods in Estonia, also distributes some well-known international brands of bicycles (the case only involved bicycles). Moreover, it operates several retail outlets throughout the country. Besides selling its bicycles through its own stores, HE had entered into contracts with independent retailers. In May 1999, HE published an advertisement for bicycles in major Estonian newspaper, which also listed several retailers from which the bicycles could be obtained, including HE and independent stores. The Competition Board noticed that the prices listed for the bicycles were the same in all retail outlets, irrespective of their ownership. Suspecting a violation of $\$ 4.1$ of the Competition Act, it initiated proceedings against $H E$ and requested $H E$ to submit all contracts that it had signed with retailers. The majority of these contracts contained a clause obliging the respective retailer to set prices equal or up to 5 per cent higher than the prices charged in Hawaii Express' outlets (of course, the independent retailers set their prices then equal to HE's prices). Some contracts specified exact margins for the retailer, which - as far as these margins equalled the ones used by Hawaii Express - also resulted in the independent retailers' prices matching the ones in HE's stores.

The Competition Board decided that all contracts examined during the investigation restricted substantially the retailers' freedom to set prices and therefore violated $\S 4.1$ of the 
Competition Act. Since HE's market share lay above 10 per cent, the "minor importance clause" for vertical agreements as laid out in $\$ 5$ was not applicable. However, during the investigations, Hawaii Express and the retailers had changed their contracts so that they were not in violation of the Competition Act anymore. The Competition Board therefore terminated its proceedings without levying a fine.

\section{The case of The Port of Veree ${ }^{48}$}

Proceedings in this dominant-position case were initiated after a complaint of several fishing companies that accused the Port of Veree of applying different charges for the unloading of ships. Fishermen selling their fish to AS Läätsa Kalatööstus - an undertaking belonging to the same parent company as the Port of Veree - had to pay a substantially lower charge (25 kroons per ton) than fishermen selling their goods to other companies (275 kroons per ton). The Competition Board concluded that due to its favourable business location with respect to fishing areas and to its high market share of around 40 per cent, the Port of Veree had a dominant position in the market for unloading fish. By making the price of its unloading service conditional on conditions not related to the provision of the service (selling the fish to AS Läätsa Kalatööstus), the Port of Veree had abused its dominant position according to $\S 16.4$ (\$ 14 under the 1998 Competition Act). The Competition Board therefore established an offence of the Competition Act and ordered the Port of Veree to end its practice and to establish unloading prices that did not depend on the sale of fish to a certain company.

These cases show that the ECB sufficiently uses its powers to initiate proceedings when it suspects a violation of the Competition Act - particularly in the cases of taxi undertakings and Hawaii Express. Also, it requests the information necessary for its investigations from the undertakings concerned - as in the submission of all of Hawaii Express' contracts with retailers. However, even though the ECB has the power to impose fines on undertakings offending the Competition Act, which it had already in 1999 and 2000 (albeit with lower upper limits), it scarcely uses this power. Only in one of the three cases described above did it impose penalties. At least in the case of the Port of Veree, an obvious case of abuse of dominance in which some of the undertaking's customers were put at a substantial competitive disadvantage, a fine would have been appropriate,

\footnotetext{
${ }^{47}$ Based on Estonian Competition Board (2000), p. 11.

${ }^{48}$ Based on Estonian Competition Board (2000), pp. 6-7.
} 
if only to establish a precedent case. Yet, the Board opted for little use of its enforcement powers and investigations with a voluntary character.

One reason for this could be that the ECB deliberately chooses an educational role in the early stages of Estonia's competition policy. The cases clearly show a very naïve behaviour of the offending undertakings: they included price-fixing agreements in their contracts (Hawaii Express), openly applied unfair pricing systems to their customers (Port of Veree) or proudly announced their agreement with competitors in a newspaper interview (taxi undertakings). This indicates that the offending undertakings were either hardly aware of the competition rules, thus acting anticompetitively without a real intention to violate any laws, or feared no severe penalties.

No matter what the reason is for these firms' open, possibly unintentional, violation of the Estonia's competition rules, the ECB will have to take adequate measures to stop it. If the problem is that - nine years after the first Competition Act was passed - still undertakings are not well enough informed about competition rules, the Board should strengthen its activities in the field of public relations, for example by distributing information brochures and guidelines for undertakings, or increasing the co-operation with universities and research institutes. Besides making potential offenders aware of Estonia's antitrust legislation and enforcement measures, this promotion could also increase the efficiency of private enforcement.

In addition, it is important that the Board strengthens the effectiveness of its own enforcement activities by using its investigative powers more effectively. Where necessary, it should rely less on co-operation with the offending undertakings. Especially, the Board should be strict about levying fines in cartel and dominant-position cases in order to create precedent cases. Although a climate of co-operation might be beneficial while the country is still in transition, a strict enforcement of the competition rules will be profitable in the long-run by making the country fit for a free market economy and for accession to the EU's internal market.

\section{Conclusions}

Estonian competition law has all the provisions that EU law has: it prohibits competition-distorting agreements and concerted practices with possible exemption clauses for efficiency reasons and block exemptions ( $\S \S 4-12)$, it prohibits the abuse of a firm's dominant position without any efficiency defence ( $\S 13-18)$, and it requires that mergers fulfilling certain conditions must be notified in advance to the competition authorities and can be prohibited if they create or enhance a dominant position which is likely to reduce or prevent competition in the respective market $(\S \S$ 
19-28). Overall, there is hardly anything in EU competition law that has not found its way into the Estonian Competition Act, often even word for word. Estonia's thus signalled intentions to mimic Europe's tradition of fighting competition-distorting conduct should weigh positively in the country's evaluation for membership.

Interestingly enough, however, while nearly everything that is in EU legislation is also in Estonia's law, the same does not hold vice versa. There are some special features and characteristics that differentiate Estonia's competition laws from that of the EU. Firstly, the Estonian Competition Act is much more compact, explicit and comprehensive than the EC Treaty and Regulations 4064/89 and 17/62. It combines the laws on all three pillars of antitrust in one document and gives many details. Sometimes, these are redundant, but overall they can be expected to benefit Estonia in its transition process, by making the new law transparent. Secondly, the Competition Act provides for more exemption clauses with respect to concerted practices than the EC Treaty does. These clauses may either benefit the economy as a whole - such as protecting the environment - or they can be expected to decrease substantially the bureaucratic burden on the Competition Board, thus increasing the efficiency of its work - such as the automatic exemption for agreements of minor importance and the safeguard clause for block exemptions. Their inclusion should therefore be applauded.

Finally, a distinctive feature of the Estonian Competition Act is that its rules also apply to government authorities. Such provisions are especially beneficial in transition economies. Yet, the present members of the European Union could benefit from the elimination of anti-competitive government regulations and behaviour as well. In these areas the EU could learn from Estonia.

Despite all similarities and positive additional features, there are some fields in which Estonian competition policy is still lagging behind EU policy. As far as legislation is concerned, the simple definition of dominance by a market share of 40 per cent or more can easily lead to erroneous investigative results. Also, the lack of thresholds for "Estonian turnover" in the paragraphs on merger control can cause problems, as it potentially forces the Competition Board to deal with mergers that could well have no noticeable anti-competitive effects.

In enforcement, the powers of the Competition Board are nearly identical to those of the European Commission. Since March 2000 the same is true for its organisational structure. However, there are several problems in the implementation of the strict enforcement of antitrust law. According to the European Commission: "the most important challenge for the Competition 
Board is to continue to ensure the effective application and enforcement of the antitrust rules." 49 One thing that is certainly needed for that is a stricter sanctioning policy.

In all, Estonia should intensify its efforts to create a real competition discipline. Increasing public awareness of the law can prevent more undertakings from violating the antitrust legislation and make private enforcement more effective. In that, making better use of the Board's investigative and penal powers can further increase efficiency, thus pushing Estonia forward on its way to a true antitrust culture.

\section{References}

1. Directorate General Competition of the European Commission, Internet page http://europa.eu.int/comm/competition/index en.html, accessed last on 22.01.2002

2. Directorate General Enlargement of the European Commission, Internet page http://europa.eu.int/comm/enlargement/intro/index_en.htm, accessed 31.01.2002

3. Estonian Competition Board, Internet page www.konkurentsiamet.ee, accessed last on 22.01.2002

4. Estonian Competition Board (2000), Annual Report 2000, www.konkurentsiamet.ee/gb/ar/2000.htm, accessed 13.12.2001

5. Estonian Competition Board (2001), Competition Act 2001, http://www.konkurentsiamet.ee/gb/compet.rtf, accessed 10.12.2001

6. European Commission (2000): 2000 Regular Report from the Commission on Estonia's Progress Towards Accession, European Commission, Brussels, http://europa.eu.int/comm/enlargement/dwu/report 11 00/pdf/en/es_en.pdf, accessed 05.09.2001

7. European Commission (2001a): Competition activity run high in 2000, Press release on 15 May 2001, Brussels, http://europa.eu.int/rapid/start/cgi/guesten.ksh?p_action.gettxt=gt\&doc=IP/01/698|0|RAPID\&l $\mathrm{g}=\mathrm{EN}$, accessed 19.01.2001

8. European Commission (2001b): 2001 Regular Report on Estonia's Progress Towards Accession, European Commission, Brussels, http://europa.eu.int/comm/enlargement/dwu/report_11_01/pdf/en/es_en.pdf, accessed 13.11.2001

9. European Council: Treaty of the European Communities (EC Treaty), http://europa.eu.int/comm/competition/legislation/treaties/ec/art81_en.html and

\footnotetext{
${ }^{49}$ European Commission (2001b), p. 44-45.
} 
http://europa.eu.int/comm/competition/legislation/treaties/ec/art82 en.html, accessed 11.12.2001

10. European Council (1962): Council Regulation 17/62, http://europa.eu.int/eurlex/en/lif/dat/1962/en 362R0017.html, accessed 11.12.2001

11. European Council (1989): Council Regulation 4064/89, http://europa.eu.int/eurlex/en/lif/dat/1989/en 389R4064.html, accessed 11.12.2001

12. Fishwick, F. (1989): "Definition of monopoly power in the antitrust policies of the United Kingdom and the European Community" in: The Antitrust Bulletin, Fall 1989, pp. 451-488

13. George, K. and A. Jacquemin (1990): "Competition Policy in the EEC" in: Comanor, W.S., K. George and others (1990): Competition Policy in Europe and North America: Economic Issues and Institutions, Harwood Academic Publishers, Chur and London, pp. 206-243

14. Kalaus, M., "Estonia: The New Competition Act Introduces Merger Contral” in: European Competition Law Review, Volume 23, Issue 6, June 2002, pp. 304-310

15. Martin, S. (1994): Industrial Economics - Economic Analysis and Public Policy, $2^{\text {nd }}$ ed., Prentice Hall, New Jersey

16. Monti, M. (2001): Enforcement of competition policy-case for the accession negotiations and for developing a real competition culture, Speech at the $7^{\text {th }}$ Annual Competition Conference between Candidate countries and the European Commission in Ljubljana/Slovenia, http://europa.eu.int/rapid/start/cgi/guesten.ksh?p action.getfile=gf\&doc=SPEECH/01/294|0|A GED\&lg=EN\&type=PDF, accessed 10.12.2001

17. OECD (1999): Competition Law and Policy in the Baltic Countries, OECD, Paris, http://www1.oecd.org/daf/clp/Publications/baltic.PDF, accessed 10 November 2001

18. Ridyard, D. (1995): Essential facilities and the obligation to supply competitors under UK and EC Competition Law, National Economic Research Associates, London 